\title{
ARCHIVAL EVIDENCE ON BIAS IN AUDITORS" ASSESSMENT OF CLIENT RISK AND THE CONSEQUENCES FOR AUDIT FEES AND AUDITOR CHANGES
}

\author{
Nicholas Hallman \\ Dr. Jere Francis, Dissertation Supervisor
}

\begin{abstract}
As part of planning and performing financial statement audits, auditors are required to make judgments regarding client risk. These judgments permeate the audit process, driving decisions regarding client acceptance, audit pricing, the extent of audit testing, and the nature of auditors' written opinions. Although auditors aim to assess each client's risk independently, prior research suggests individuals' draw on their idiosyncratic experiences and environments for benchmarks against which to contrast the case at hand. These "contrast effects" can result in judgments that deviate from those that would be reached using normative principles and may cause bias in auditors' assessment of client risk. Consistent with this theory, the archival evidence presented in this paper shows that, after controlling for clients' actual risk levels, auditors perform more (less) conservative audits and charge higher (lower) audit fees when clients appear riskier (less risky) in the context of other clients audited by the same practice office. Moreover, clients subject to increased (decreased) conservatism and higher (lower) audit fees due to auditors' biases are more (less) likely to switch auditors during the following period.
\end{abstract}

